\title{
Procedural Fairness and the Unjustified Dismissal Decision
}

\author{
Bronwyn Boon*
}

Clause 17(3) of the Employment Contracts Bill (1990) sought to remove consideration of procedural fairness from the unjustified dismissal decision. While this clause failed to survive the second reading, an important hypothetical question remains: what impact would legislation such as this have on the unjustified dismissal decision? By way of addressing this question, the results of a survey of dismissal appeals heard under the Labour Relations Act (1987) are reported. The discussion suggests that hypothetically, removal of procedural fairness would have a major impact on the appeal decision, reducing the number of dismissals overturned by $25 \%$. However on a practical level it is suggested that the issues of procedural fairness would be incorporated into the assessment of substantive justification. Conclusions also consider the nonsense produced by the clause, in leaving administration of a personal grievance procedure to the judiciary while at the same time restricting use of the principles by which they operate.

\section{Introduction}

Effective personal grievance legislation has been in place in New Zealand since 1973. The impetus behind this legislation was the increasing industrial disruption caused by dismissals. The Industrial Relations (IR) Act and the Labour Relations (LR) Act both described a procedure by which a worker could appeal a dismissal. However neither Act prescribed the definition and criteria to be used by the procedure. As a result of this vague language and the appeal nature of the legislation, the labour courts were left the role of establishing a working definition of "unjustifiable" and the development of criteria by which that could be determined. Through a series of rulings, the meaning of "unjustifiable" became strongly connected to the notion of procedural fairness. The Employment Contracts Bill (ECB) of 1990 contained $\mathrm{cl} \mathrm{17(3)}$ which sought to dissolve the influence of procedural fairness on the unjustified dismissal decision. Although this clause was removed from the final draft of the Bill, it promotes thought concerning the impact procedural fairness has on the unjustified dismissal decision and hence the effect such legislation would have.

In order to suggest possible effects, a sample of dismissal appeal decisions heard under the LR Act during the period 1987 to 1991 were examined. Of the 597 cases reviewed, 287 were from the Labour Court and 310 from the Mediation Service. Before reporting on the results of this study a brief introduction to the nature of dismissal legislation in New Zealand will be presented, along with the interpretation of "unjustifiable", and the position of procedural faimess in that interpretation and the subsequent ECB (1990). Conclusions will present the impact of $\mathrm{cl} \mathrm{17(3)}$ suggested by the study results and the nature of dismissal legislation in New Zealand.

- Department of Management, University of Otago. The author is grateful to Alan Geare, Ian McAndrew and anonymous journal referees for their helpful comments, and to the Industrial Relations Service of the Department of Labour for assistance with data access. 


\section{The nature of New Zealand dismissal legislation}

Labour legislation, particularly in the private sector, has played an important part in the regulation of the employment relationship in New Zealand for almost a century, the first notable piece of legislation being the Industrial Conciliation and Arbitration (ICA) Act of 1894. While the ICA Act sought to provide a regulatory framework for the resolution of interest disputes, disputes of right (under which personal grievances are grouped) were specifically excluded as it was believed they were not sufficiently problematic to warrant state interference (Reeves, 1902).

Although limitations with respect to dismissals were first introduced by the ICA Amendment (ICAA) Act of 1903, these were confined to the area of discrimination due to union membership or entitlements under an award or agreement. Until 1970, a worker not eligible to appeal a dismissal under the ICAA Act had two options available: to appeal to common law procedures or to gain support from their union to strike in protest (Anderson, 1988).

The first piece of legislation to include a personal grievance appeal procedure and remedy was the ICAA Act of 1970 . While designed to give a worker the opportunity to appeal a wrongful dismissal, this Act was seen primarily as an attempt to curb industrial disruption and not as a specific plan to deal with the problem of job security (Hughes, 1989; Anderson, 1988). However due to the legislation adopting the common law terminology of "wrongful dismissal", the Act resulted in little change to the status quo.

The 1973 Industrial Relations (IR) Act expanded the personal grievance section in two ways. Under the Act, a procedure for the resolution of personal grievances had to be contained in all awards and agreements; and the term unjustifiable dismissal was substituted for wrongful dismissal. Specifically a personal grievance was defined as "a grievance that a worker may have against his employer because of a claim that he has been unjustifiably dismissed, or that other action by the employer ... affects his employment to his disadvantage".

The Labour Relations (LR) Act of 1987 broadened coverage of the procedure. Amongst other changes, it introduced the possibility of appealing the mediator's decision and extended access to non-union members, although they had to join a union before proceedings were initiated. While the procedure was enhanced, no specific guidance was offered as to the definition of unjustifiable nor the criteria to be used in the assessment of unjustifiable behaviour.

The law of employment as it exists in Anglo-American systems, has essentially been a mix of three policies: protection and guidance for the employer-employee relationship; the exercise of state power to regulate the employer-employee relationship; and freedom of contract (Selznik, 1969). Personal grievance law is essentially that of protection and guidance for the employer-employee relationship and the exercise of state power to regulate the employer-employee relationship. This can be translated into: protection and guidance through legislation covering pre-dismissal procedures; and the use of state power to regulate through a procedure of appeal to a neutral party. On the international continuum, New Zealand is placed at the highly undeveloped pre-dismissal end, "appear(ing) to disregard this field almost entirely"; however a developed appeal structure is said to provide an effective protection for employees (Bandaret, 1986: 397).

While all awards and agreements were required to contain a procedure for appealing 
a dismissal (at least as comprehensive as the procedure set out in the acts) few provided a complete or even partial pre-dismissal procedure (Anderson, 1983). Hughes (1981: 170) suggests that "many of the problems giving rise to personal grievances might be resolved by written disciplinary procedures".

This emphasis on the post-dismissal appeal to a legal authority, in conjunction with vague legislative language, has meant that the labour courts have had considerable influence over the working details of personal grievance law. In fact "substantive law governing personal grievance in New Zealand is thus almost entirely a creation of the court and of the court of appeal .." (Anderson, 1988: 264).

\section{The Interpretation of "Unjustifiable"}

An important example of this influence is the definition of "unjustifiable" in the context of an unjustifiable dismissal. The 1973 Act introduced the term unjustifiable but provided little guidance as to a working definition of the term. The court in Auckland Local Authorities Officers' IUW $v$ Waitemata City Council (1980: 35) dealt with it by "act(ing) on the principle that the change of words was deliberate and the common law authorities on wrongful dismissal have had little or no application to the concept of unjustified dismissal".

In 1980 Chief Judge Horn of the Arbitration Court in Taranaki Amalgamated Society of Shop Assistants and Related Trades IUW v CC Ward Ltd (1980: 124) was loathe to "set down rigid rules by way of precedent" and suggested that as "(t)he legislature has not seen fit to define unjustified dismissal .. the court draws the inference that each "case must be considered individually taking into account all surrounding circumstances". Criticism was directed towards the court for this lack of guidance. Hughes (1981) disagreed with Chief Judge Horn's inference, claiming that, because the statutory wording was so vague, it was up to the court to establish some guidelines for the participants in the personal grievance procedure. For Mathieson (1981: 218) "the court ha(d) failed to do what Parliament intended that it should do, namely construct and develop a body of case law that would enhance predictability and reduce the number of references actually reaching the court".

The watershed case of Auckland City Council v Hennessey (1982: 699-702) finally gave some guidance to the meaning of unjustifiable, although Hughes suggests that the case itself, "merely recognised existing practice" (Hughes, 1991: 13). In his report, Judge Somers considered that,

(i)n the context of $\$ 117$ we find the word unjustified should have its ordinary accepted meaning. Its integral feature is the word unjust - that is to say not in accordance with justice or faimess. A course of action is unjustifiable when that which is done cannot be shown to be in accordance with justice or faimess (1982: 699).

\section{Procedural Fairness and the Unjustified Dismissal}

The major significance of the court's definition of unjustifiable, has been an acceptance of the need for fair procedure during the dismissal of an employee. Fair procedure has evolved as a combination of natural justice and good industrial relations practice (Anderson, 1988). A guidebook to New Zealand employment law defines natural justice as an "administrative law concept relevant to industrial law"(CCH: 611$)$. In this context natural 


\section{Bronwyn Boon}

justice carries specific meaning incorporating two rules: the hearing rule and the bias rule. For the most part it is the hearing rule that features in labour case law. Under this rule: the person making the decision must afford the person whom the decision will affect, the opportunity to put forward their side of the case (Hotop, 1985).

The Hennessey case is commonly cited to illustrate the recognition by labour law of this principle of natural justice. The Court of Appeal, while avoiding the setting of firm rules, interpreted the term unjustifiable so as to accommodate procedural inadequacies adopted by the employer (Hughes, 1989: 1931); specifically, inadequate opportunity for the employee to state their side of the case (Anderson, 1983). Since this decision, further elements of procedural fairness have been articulated. In addition to the opportunity to be heard is the requirement for a full investigation of the case and sufficient warnings concerning inadequate performance or inappropriate behaviour.

Up to this point, the procedure referred to involves the implied standards of an employment relationship. Consideration is also given to the adherence of a much more explicit discipline procedure contained in an award/agreement. In such cases, "the court has generally taken the attitude that the failure to follow an agreed procedure will render the dismissal unjustified" (Anderson, 1983: 3).

\section{Procedural fairness and the Employment Contracts Bill (1990)}

The Employment Contracts Bill (ECB) tabled by the National Government at the end of 1990 , included $\mathrm{cl} \mathrm{17(3)} \mathrm{which} \mathrm{sought} \mathrm{to} \mathrm{remove} \mathrm{procedural} \mathrm{fairness} \mathrm{from} \mathrm{the} \mathrm{unjustifiable}$ dismissal arena by declaring that:

the failure by an employer to observe, follow, or adhere to any procedural requirements (whether imposed by law or by contract or otherwise) in making a decision to dismiss an employee shall not of itself render that dismissal unjustifiable if, but for that failure, the dismissal would otherwise have been substantively justifiable" (ECB, 1990).

In his speech introducing the Bill, the Minister of Labour considered that the Bill would enable "only dismissals that are unjustified in substance (to) be ruled unjustifiable.. resolv(ing) a problem created by a decision of the Labour Court" (Hansard, 1990: 480).

Some debate ensued over the merits and the actual meaning of the clause. The Law Commission suggested that the Court of Appeal decision in the Hennessey case was the reason behind the inclusion of this clause into the ECB and went on to recommend that a change of terminology from unjustifiable dismissal to without good reason "would permit concentration on substantive rather than procedural aspects of dismissal" (NZLC R18, 1991: 57).

The New Zealand Employers' Federation endorsed the "positive changes" in the Bill, commenting some time later that the "concern that a termination can be held to be unjustifiable because of the way it is carried out, regardless of the substantive reasons, is an inhibiting factor to some employers expanding their operations and employing more staff" (NZEF 1991: 3). While the Council of Trade Unions, not unexpectedly, opposed the inclusion of $\mathrm{cl} \mathrm{17(3)}$ in the legislation, the New Zealand Business Roundtable favoured the removal of personal grievance procedures from the legislation completely (Hughes, 1992).

Hughes (1991: 14) describes the drafting of the Bill, as "self-contradictory" and "conceptually confusing" and he is left wondering, "what the distinction between the two 
concepts (procedural and substantive fairness) is thought to be". He goes on to suggest that "the employer will be faced at the hearing with the task of proving that ... the particular breach of procedural fairness made no difference to the decision on the substantive merits as they appear at the hearing (ibid:16).

In addition, he noted the possibility that the employer will also be able to ignore aspects of procedure negotiated by the parties into the agreement or award, particularly in the case of redundancy provisions "which will always be substantively justifiable" (ibid: 17). Geare (1991) comments that little thought had actually gone into the clause, and that in reality procedural and substantive issues are usually closely connected.

By the second reading of the Bill, on 23 April 1991, the Minister of Labour informed the house that "(a) large number of submissions were received on clause 17(3) .. (and) .. that has now been deleted" (Hansard, 1991: 1438).

\section{The survey of unjustified dismissal cases}

Although not included in the final version of the Employment Contracts (EC) Act, cl 17(3) does raise the question: what impact would such a provision have on the unjustifiable dismissal decision? In order to examine this question, a survey was undertaken to isolate the current impact of procedural fairness violation. The study focused on the stated rationale for the unjustifiable dismissal decision.

\section{The Data}

The data was drawn from published and unpublished personal grievance decisions issued by the Labour Court and the Mediation Service. Labour Court cases included all decisions alleging unjustifiable dismissal between the period August 1987 and August 1991 . Cases involving procedural issues such as claims to the Court for a direct hearing were excluded from the sample, leaving a total of 287 cases. In addition, courtesy of the Department of Labour Industrial Services Unit, a small random sample of Mediation Service rulings from 1990 was included. Every second case from the available set of 1990 decisions was selected. Of this sample of 310,159 were decided by the Grievance Committee and 151 were decided by the chair (the mediator). The total study sample consisted of 597 cases. Table 1 presents a breakdown of the data by year and source.

\section{The Results of the Study}

Analysis of each case was undertaken through a series of steps. Results of the study will be presented by way of these steps. The percentages of cases found to be unjustified will be given before going on to the bases upon which the decision was made. The following analysis focused on what the decision maker actually stated or discussed in the report. At times these discussions contained reference to particular factors without necessarily stating them explicitly. Inter-rater reliability tests were conducted and were at a statistically satisfactory level.

For the purposes of this study, procedural issues have been defined as distinct from 
substantive issues. Initial analysis sought to establish the frequencies of each as a basis for the "unjustified" decision. As the focus of this study was procedural fairness, a closer look was taken at the issues defined as procedural. Initially this was in terms of the nature of the procedural violation, whether it was neglect of a written procedure in a document or implied requirements of procedural fairness for "natural justice". In turn, attention was drawn to the particular principles within the concept of natural justice and finally the specific issues involved in these principles.

Table 1: The Data

\begin{tabular}{||c||c|c||c||}
\hline Year & Labour Court & $\begin{array}{c}\text { Mediation } \\
\text { Service }\end{array}$ & Total \\
\hline \hline 1987 & 11 & & 11 \\
\hline 1988 & 65 & & 65 \\
\hline 1989 & 78 & & 78 \\
\hline 1990 & 88 & 310 & 398 \\
\hline 1991 & 45 & & 45 \\
\hline \hline Total & 287 & 310 & 597 \\
\hline
\end{tabular}

\section{$\underline{\text { Step One }}$}

Each case was initially analyzed in terms of the final decision. Of the total number of cases heard in the Labour Court between 1987 and 1990, just on 75\% were found to be unjustified. In 1991 this figure dropped to $54 \%$. Of the Mediation Service sample, $100 \%$ of dismissal disputes settled by the personal grievance committee and $57 \%$ of those arbitrated by the chair were found to be unjustified. The committee level result is an expected outcome of the process. As resolution at this level requires a negotiated settlement, to some extent the process forces the implication that the dismissal was unjustified. It is acknowledged, however, that settlements are negotiated under a variety of pressures and not all cases carry an acceptance of wrong-doing by either party. If settlement was not arrived at, the dispute would not be resolved at this level but passed on to the chair or the Labour Court to decide.

\section{$\underline{\text { Step Two }}$}

Procedural fairness on a broad level covers the actions by an employer leading up to and at the time of a dismissal. In other words, the way in which a dismissal was carried out. Substantive justification in this study is defined essentially as failure to prove minimal justification for the dismissal. This definition of substantive justification does simplify a 
potentially complex class by excluding any account of procedure. Szakats \& Mulgan (1990), Hughes (1991) and Geare (1991) all refer to the strong inter-connection between substantive and procedural issues. The definition used in this study does not seek to ignore or even refute this approach, but merely elevate the level of analysis of this class in order to exclude implied reference to procedural matters. Table 2 profiles the findings.

Table 2: Reasons for the Unjustified Dismissal Decision

\begin{tabular}{|c|c|c|c|c|c|c|c|}
\hline \multicolumn{6}{|c|}{ Court } & Chair & Total \\
\hline \multirow[b]{2}{*}{$\begin{array}{l}\text { Total cases found } \\
\text { unjustifiable }\end{array}$} & 1987 & 1988 & 1989 & 1990 & 1991 & 1990 & \\
\hline & 8 & 48 & 57 & 64 & 25 & 86 & 288 \\
\hline $\begin{array}{l}\text { Cases involving } \\
\text { procedural } \\
\text { inadequacies }\end{array}$ & $\begin{array}{c}6 \\
(75 \%)\end{array}$ & $\begin{array}{c}40 \\
(83 \%)\end{array}$ & $\begin{array}{c}51 \\
(89 \%)\end{array}$ & $\begin{array}{c}54 \\
(84 \%)\end{array}$ & $\begin{array}{c}22 \\
(88 \%)\end{array}$ & $\begin{array}{c}78 \\
(90 \%)\end{array}$ & $\begin{array}{c}250 \\
(87 \%)\end{array}$ \\
\hline $\begin{array}{l}\text { Cases involving lack } \\
\text { of substantive } \\
\text { justification }\end{array}$ & $\begin{array}{c}7 \\
(87 \%)\end{array}$ & $\begin{array}{c}33 \\
(69 \%)\end{array}$ & $\begin{array}{c}29 \\
(50 \%)\end{array}$ & $\begin{array}{c}16 \\
(25 \%)\end{array}$ & $\begin{array}{c}15 \\
(60 \%)\end{array}$ & $\begin{array}{c}29 \\
(33 \%)\end{array}$ & $\begin{array}{c}129 \\
(45 \%)\end{array}$ \\
\hline
\end{tabular}

Remembering that cases may involve both substantive and procedural issues in the decision, well over three-quarters of the cases involved procedural inadequacies while almost half contained a lack of substantive justification. These results suggest that assessment of employer action with respect to fair procedure is an important aspect of the decision-making process.

\section{$\underline{\text { Step Three }}$}

As the focus of the study was procedural faimess, step three took a closer look at the nature of the procedural violations. These violations were organised into two categories covering "formal" procedure and "natural justice" based procedure. Formal procedural inadequacy is defined as the adherence to a formal pre-dismissal procedure contained within the document covering the employee's terms and conditions of work. Natural justice procedural inadequacy on the other hand is the assessment of the employer's actions surrounding the time of the dismissal; particularly with respect to consistency with the established principles of natural justice. Table 3 presents the results of this breakdown of procedure.

Again cases may cite more than one basis for the dismissal to be found unjustifiable. Overall, inadequacies with respect to natural justice procedure outweigh those concerning formal procedure. Formal procedure is involved in one case for every nine involving natural justice procedure. Such a result is not surprising considering the small number of predismissal procedures reported in the documents covering employees' terms and conditions of employment. 
Table 3: The Nature of the Procedural Inadequacies

\begin{tabular}{|c|c|c|c|c|c|c|c|}
\hline \multicolumn{6}{|c|}{ Court } & \multirow{2}{*}{$\begin{array}{l}\text { Chair } \\
1990 \\
\end{array}$} & \multirow{3}{*}{$\begin{array}{r}\text { Total } \\
288\end{array}$} \\
\hline & 1987 & 1988 & 1989 & 1990 & 1991 & & \\
\hline $\begin{array}{l}\text { Total cases found } \\
\text { unjustifiable }\end{array}$ & 8 & 48 & 57 & 64 & 25 & 86 & \\
\hline $\begin{array}{l}\text { Cases that involve } \\
\text { natural justice } \\
\text { procedural } \\
\text { inadequacies }\end{array}$ & 5 & 39 & 45 & 39 & 22 & 75 & 225 \\
\hline $\begin{array}{l}\text { Cases that involve } \\
\text { formal procedural } \\
\text { inadequacies }\end{array}$ & 1 & 1 & 6 & 15 & 5 & 3 & 25 \\
\hline $\begin{array}{l}\text { Ratio of natural } \\
\text { justice to formal } \\
\text { procedure }\end{array}$ & $5: 1$ & $39: 1$ & $7.5: 1$ & $2.6: 1$ & $4.4: 1$ & $25: 1$ & $9: 1$ \\
\hline
\end{tabular}

\section{$\underline{\text { Step Four }}$}

Step four involved a closer look at procedural violations incorporating the concept of natural justice. In the area of labour law, natural justice consists of three broad principles: the opportunity to explain, adequate investigation of the facts and adequate warnings. Table 4 offers the breakdown of natural justice violations in terms of these three principles.

The opportunity to explain and the adequate investigation of the facts are cited in virtually equal numbers by the decision-makers in their decisions to overturn dismissals. The provision of adequate warnings was reported to be less often a problem.

\section{$\underline{\text { Step Five }}$}

Step five in the analysis concerned the specific issues within the three broad principles of natural justice. The failure to provide an opportunity to explain category covers: no chance for employees to present their side of the case, pre-judgement of the dismissal decision, poor union representation and the unavailability of the reason for the dismissal. The chance for an employee to be heard is taken directly from the principles of natural justice in administrative law, with the 1982 Court of Appeal Hennessey decision confirming the relevance of this principle in labour law. Pre-judgement of the decision to dismiss is where the decision to dismiss had clearly been made prior to a meeting between the parties involved. The impact of poor union representation at the time of the dismissal will vary from case to case and employee to employee. While some employees may be both aware of their rights and be able to defend themselves adequately in a dismissal situation, there will be others for whom representation is very much necessary. Poor representation deals with the actual presence and/or the invitation to be present of a support person for the employee, either at 
Table 4: The Principles of Natural Justice Involved in Procedural Violation

\begin{tabular}{|c|c|c|c|c|c|c|c|}
\hline \multicolumn{6}{|c|}{ Court } & \multirow{2}{*}{$\frac{\text { Chair }}{1990}$} & Total \\
\hline & 1987 & 1988 & 1989 & 1990 & 1991 & & \multirow[b]{2}{*}{225} \\
\hline $\begin{array}{l}\text { Total cases } \\
\text { involving natural } \\
\text { justice } \\
\text { inadequacies }\end{array}$ & 5 & 39 & 45 & 39 & 22 & 75 & \\
\hline $\begin{array}{l}\text { Cases involving } \\
\text { failure to provide } \\
\text { the opportunity to } \\
\text { explain }\end{array}$ & $\begin{array}{c}5 \\
(100 \%)\end{array}$ & $\begin{array}{c}25 \\
(64 \%)\end{array}$ & $\begin{array}{c}30 \\
(66 \%)\end{array}$ & $\begin{array}{c}30 \\
(77 \%)\end{array}$ & $\begin{array}{c}13 \\
(59 \%)\end{array}$ & $\begin{array}{c}43 \\
(29 \%)\end{array}$ & $\begin{array}{c}146 \\
(65 \%)\end{array}$ \\
\hline $\begin{array}{l}\text { Cases involving } \\
\text { inadequate } \\
\text { investigation of } \\
\text { the facts }\end{array}$ & $\begin{array}{c}2 \\
(40 \%)\end{array}$ & $\begin{array}{c}29 \\
(74 \%)\end{array}$ & $\begin{array}{c}36 \\
(80 \%)\end{array}$ & $\begin{array}{c}15 \\
(38 \%)\end{array}$ & $\begin{array}{c}16 \\
(72 \%)\end{array}$ & $\begin{array}{c}50 \\
(33 \%)\end{array}$ & $\begin{array}{c}148 \\
(66 \%)\end{array}$ \\
\hline $\begin{array}{l}\text { Cases involving } \\
\text { inadequate } \\
\text { warnings }\end{array}$ & $\begin{array}{c}2 \\
(40 \%)\end{array}$ & $\begin{array}{c}20 \\
(51 \%)\end{array}$ & $\begin{array}{c}21 \\
(47 \%)\end{array}$ & $\begin{array}{c}16 \\
(41 \%)\end{array}$ & $\begin{array}{c}9 \\
(41 \%)\end{array}$ & $\begin{array}{c}43 \\
(29 \%)\end{array}$ & $\begin{array}{c}111 \\
(49 \%)\end{array}$ \\
\hline
\end{tabular}

NB Cases may cite more than one basis for the decision

the time of the dismissal or at meetings concerning a dismissal. The reason for the dismissal is a necessary ingredient for the development of any defence. If no reason is provided, there is little opportunity for employees to explain their side of the case and defend the accusations made against them. At times employers may simply fail to provide any reason, while at others they may provide a covering reason, one felt to be more legitimate or acceptable. Table 5 profiles the issues within the principle of inadequate opportunity to explain.

Well over one-half of the cases involve failure in the opportunity for the employee to be heard, while pre-judgment and failure to provide reasons are present in a little over onethird of cases each. Union representation on the other hand, is inadequate in a small number of cases only.

Inadequate investigation consists of: poor investigation of the facts, wrong interpretation of the facts, problems with the evidence and undue haste in the decision to dismiss. There is an obligation for any employer dismissing an employee to prove that the employee did commit an offence worthy of the discipline of dismissal. In turn, this proof must be established by an adequate investigation of the facts surrounding the events that lead to the dismissal. Tied in with proof of an offence and investigation of the facts is the 
Table 5: The Specific Issues Involved in the Inadequate Opportunity to Explain

\begin{tabular}{|c|c|c|c|c|c|c|c|}
\hline \multicolumn{6}{|c|}{ Court } & \multirow{2}{*}{$\frac{\text { Chair }}{1990}$} & Total \\
\hline & 1987 & 1988 & 1989 & 1990 & 1991 & & \multirow[b]{2}{*}{146} \\
\hline $\begin{array}{l}\text { Total cases } \\
\text { involving no } \\
\text { opportunity } \\
\text { to explain }\end{array}$ & 5 & 25 & 30 & 30 & 13 & 43 & \\
\hline $\begin{array}{l}\text { No chance to } \\
\text { be heard }\end{array}$ & $\begin{array}{c}2 \\
(40 \%)\end{array}$ & $\begin{array}{c}18 \\
(72 \%)\end{array}$ & $\begin{array}{c}16 \\
(53 \%)\end{array}$ & $\begin{array}{c}17 \\
(57 \%)\end{array}$ & $\begin{array}{c}8 \\
(61 \%)\end{array}$ & $\begin{array}{c}21 \\
(49 \%)\end{array}$ & $\begin{array}{c}82 \\
(56 \%)\end{array}$ \\
\hline $\begin{array}{l}\text { Pre- } \\
\text { judgement of } \\
\text { the decision } \\
\text { to dismiss }\end{array}$ & $\begin{array}{c}1 \\
(20 \%)\end{array}$ & $\begin{array}{c}9 \\
(36 \%)\end{array}$ & $\begin{array}{c}17 \\
(56 \%)\end{array}$ & $\begin{array}{c}13 \\
(43 \%)\end{array}$ & $\begin{array}{c}7 \\
(54 \%)\end{array}$ & $\begin{array}{c}10 \\
(23 \%)\end{array}$ & $\begin{array}{c}57 \\
(39 \%)\end{array}$ \\
\hline $\begin{array}{l}\text { Poor union } \\
\text { represen- } \\
\text { tation }\end{array}$ & $\begin{array}{c}2 \\
(40 \%)\end{array}$ & $\begin{array}{c}3 \\
(12 \%)\end{array}$ & $\begin{array}{c}4 \\
(13 \%) \\
\end{array}$ & $\begin{array}{c}7 \\
(23 \%) \\
\end{array}$ & $\begin{array}{c}1 \\
(8 \%) \\
\end{array}$ & $\begin{array}{c}4 \\
(9 \%) \\
\end{array}$ & $\begin{array}{c}21 \\
(14 \%)\end{array}$ \\
\hline $\begin{array}{l}\text { Reason for } \\
\text { dismissal not } \\
\text { given }\end{array}$ & 0 & $\begin{array}{c}6 \\
(24 \%)\end{array}$ & $\begin{array}{c}11 \\
(36 \%)\end{array}$ & $\begin{array}{c}17 \\
(56 \%)\end{array}$ & $\begin{array}{c}5 \\
(38 \%)\end{array}$ & $\begin{array}{c}14 \\
(32 \%)\end{array}$ & $\begin{array}{c}53 \\
(36 \%)\end{array}$ \\
\hline
\end{tabular}

$\underline{\text { NB }}$ Cases may cite more than one basis for the decision

correct interpretation of the facts. In this category, the decision maker had to have been convinced that the employer interpreted the facts in a reasonable way. Also connected to the collection and interpretation of the facts is the quality of the evidence. In order to prove the validity of the decision to dismiss, an employer must be able to provide adequate evidence of the offence. Undue haste in the decision to dismiss covers a general requirement to avoid making a hasty decision. While this may be influenced by a general lack of fact gathering, it specifically reflects a situation that has got out of hand and has resulted in a summary dismissal where none was initially intended or in fact warranted. Table 6 provides the results of the specific issues of inadequate investigation.

The results in this table indicate that the investigation of the facts is less of a problem than the interpretation of the facts and the production of adequate evidence.

The inadequate warnings category consists of: failure to provide sufficient warnings, failure to discuss reports with the employee and failure to provide an opportunity to improve. Otherwise known as progressive discipline, the need for sufficient warnings comes from the implied responsibility of an employer to administer discipline as a corrective rather than a punitive measure (Summers, 1976). At times the issue of warnings may be strongly implicated in the substantive justification of the dismissal. For example: a relatively minor offence, such as being late for work, may be inadequate to substantively justify a dismissal. 
Procedural Fairness

Table 6: Specific Issues Within Inadequate Investigation of the Facts

\begin{tabular}{||l|c|c|c|c|c||c||c||}
\hline \multicolumn{1}{|c|}{ Court } & 1987 & 1988 & 1989 & 1990 & 1991 & 1990 & \\
\cline { 2 - 8 } & 2 & 29 & 36 & 15 & 16 & 50 & 148 \\
$\begin{array}{l}\text { Total cases } \\
\text { involving } \\
\text { inadequate } \\
\text { investigation }\end{array}$ & 0 & 12 & 9 & 8 & 1 & 7 & 37 \\
\hline \hline $\begin{array}{l}\text { Poor } \\
\text { investigation } \\
\text { of the facts }\end{array}$ & 1 & 10 & 22 & 10 & 9 & 19 & 71 \\
\hline $\begin{array}{l}\text { Wrong } \\
\text { interpretation } \\
\text { of the facts }\end{array}$ & $(50 \%)$ & $(34 \%)$ & $(61 \%)$ & $(66 \%)$ & $(56 \%)$ & $(38 \%)$ & $(48 \%)$ \\
\hline $\begin{array}{l}\text { Problems with } \\
\text { the evidence }\end{array}$ & 1 & 16 & 11 & 4 & 7 & 30 & 69 \\
\hline $\begin{array}{l}\text { Undue haste } \\
\text { in the decision } \\
\text { to dismiss }\end{array}$ & 1 & 5 & 6 & 0 & 3 & 0 & 15 \\
\hline \hline
\end{tabular}

NB Cases may cite more than one basis for the decision

However, with a sufficient number of warnings to the employee regarding habitual lateness for work, the offence may become severe enough to warrant dismissal. At times, the distinction between procedural and substantive issues is rather vague. In order to deal with that area of ambiguity in this study, the issue of sufficient warning is restricted to the statement by the decision-maker that there was insufficient warning given to the employee prior to the dismissal. Insufficient warnings are found both in cases of incompetence and misconduct. Discussion of reports with the employee usually involves complaints made against the employee. While associated with warnings generally, this discussion can also provide an opportunity to explain the employee's side of the case. Also related to warnings is the opportunity to improve behaviour and work performance. Once warned an employee must then be given an opportunity to improve or change the undesirable behaviour. This opportunity must be a real opportunity in terms of both time and provisions for the improvement. Table 7 profiles the issues under specific warnings.

Of the specific issues under the principle of adequate warnings, by far the most common deficiency lies in the actual administration of sufficient warnings. The lack of warning accounts for almost four times the number of cases dealing with lack of opportunity to improve. 


\section{Bronwyn Boon}

Table 7: Specific Issues Within Inadequate Warnings

\begin{tabular}{|c|c|c|c|c|c|c|c|}
\hline & & & & & Court & Chair & Total \\
\hline \multirow[b]{2}{*}{$\begin{array}{l}\text { Total cases } \\
\text { involving } \\
\text { inadequate } \\
\text { warnings }\end{array}$} & 1987 & 1988 & 1989 & 1990 & 1991 & 1990 & \multirow[b]{2}{*}{111} \\
\hline & 2 & 20 & 21 & 16 & 9 & 43 & \\
\hline $\begin{array}{l}\text { Failure to provide } \\
\text { sufficient } \\
\text { warnings }\end{array}$ & $\begin{array}{c}1 \\
(50 \%)\end{array}$ & $\begin{array}{c}19 \\
(95 \%)\end{array}$ & $\begin{array}{c}19 \\
(90 \%)\end{array}$ & $\begin{array}{c}16 \\
(100 \%)\end{array}$ & $\begin{array}{c}9 \\
(100 \%)\end{array}$ & $\begin{array}{c}37 \\
(86 \%)\end{array}$ & $\begin{array}{c}101 \\
(91 \%)\end{array}$ \\
\hline $\begin{array}{l}\text { Failure to discuss } \\
\text { reports with } \\
\text { employee }\end{array}$ & $\begin{array}{c}1 \\
(50 \%)\end{array}$ & $\begin{array}{c}6 \\
(30 \%)\end{array}$ & $\begin{array}{c}3 \\
(14 \%)\end{array}$ & 0 & 0 & $\begin{array}{c}3 \\
(7 \%) \\
\end{array}$ & $\begin{array}{c}13 \\
(12 \%)\end{array}$ \\
\hline $\begin{array}{l}\text { Opportunity to } \\
\text { improve not } \\
\text { provided }\end{array}$ & $\begin{array}{c}1 \\
(50 \%)\end{array}$ & $\begin{array}{c}6 \\
(30 \%)\end{array}$ & $\begin{array}{c}3 \\
(14 \%)\end{array}$ & 0 & $\begin{array}{c}3 \\
(33 \%)\end{array}$ & $\begin{array}{c}13 \\
(30 \%)\end{array}$ & $\begin{array}{c}26 \\
(23 \%)\end{array}$ \\
\hline
\end{tabular}

NB Cases may cite more than one basis for the decision

\section{$\underline{\text { Step Six }}$}

Although the focus of the study was on matters of procedural faimess, specific issues contained within substantive inadequacies were also looked at. Substantive inadequacies concern failure to prove that the dismissal was an appropriate discipline and that consideration had been taken of the employee's work history. Table 8 profiles the specific issues under substantive inadequacies.

The results suggest that by far the most important aspect determining the substantive justification for the dismissal is the inappropriate severity of the discipline of dismissal for the situation.

\section{Discussion}

Overall, three-quarters of the dismissal cases studied were found to be unjustified. Most of the decisions involved were based at least in part, on matters of unfair procedure, while only half involved lack of substantive justification. This reflects the importance attached by the decision-maker to the standards of fair procedure, and in particular, fair procedure according to the tenets of natural justice. This profile is not surprising in view of the low incidence of pre-dismissal procedures negotiated into documents covering employees' terms and conditions of employment. In addition it reflects the influence of the courts on the personal grievance procedure. 
Table 8: Specific Issues under Substantive Inadequacies

\begin{tabular}{|c|c|c|c|c|c|c|c|}
\hline \multicolumn{6}{|c|}{ Court } & \multirow{2}{*}{$\begin{array}{l}\text { Chair } \\
1990 \\
\end{array}$} & Total \\
\hline & 1987 & 1988 & 1989 & 1990 & 1991 & & \multirow[b]{2}{*}{129} \\
\hline $\begin{array}{l}\text { Total cases } \\
\text { involving lack } \\
\text { of substantive } \\
\text { justification }\end{array}$ & 7 & 33 & 29 & 16 & 15 & 29 & \\
\hline $\begin{array}{l}\text { Inappropriate } \\
\text { discipline for } \\
\text { the situation }\end{array}$ & $\begin{array}{c}7 \\
(100 \%)\end{array}$ & $\begin{array}{c}31 \\
(94 \%)\end{array}$ & $\begin{array}{c}27 \\
(93 \%)\end{array}$ & $\begin{array}{c}16 \\
(100 \%)\end{array}$ & $\begin{array}{c}14 \\
(93 \%)\end{array}$ & $\begin{array}{c}24 \\
(83 \%)\end{array}$ & $\begin{array}{c}119 \\
(92 \%)\end{array}$ \\
\hline $\begin{array}{l}\text { Failure to take } \\
\text { consideration } \\
\text { of good work } \\
\text { history }\end{array}$ & $\begin{array}{c}2 \\
(28 \%)\end{array}$ & $\begin{array}{c}10 \\
(30 \%)\end{array}$ & $\begin{array}{c}5 \\
(17 \%)\end{array}$ & $\begin{array}{c}2 \\
(12 \%)\end{array}$ & $\begin{array}{c}2 \\
(13 \%)\end{array}$ & $\begin{array}{c}8 \\
(27 \%)\end{array}$ & $\begin{array}{c}29 \\
(22 \%)\end{array}$ \\
\hline
\end{tabular}

$\underline{\mathrm{NB}}$ Cases may cite more than one basis for the decision

Literature and case law express three main principles of natural justice: the opportunity to explain, a full investigation of the facts and adequate warnings. The results of this study indicate that the first two principles are performed inadequately by employers in an equal and large number of dismissals, while inadequate warnings are present as a somewhat less frequent violation. This may suggest that, on the whole, New Zealand employers provide adequate warnings to their employees; however, perhaps it also reflects the derivation of the principles.

An opportunity to explain and adequate investigation of the facts are generally accepted as legitimate requirements of fair employer behaviour. However they are also specifically relevant to other aspects of judicial control, such as criminal law. Warnings, on the other hand, derive from the implied responsibility of an employer to be a reasonable employer. A possible explanation behind the greater use of standard legal issues is that the legal system has a higher sensitivity to inadequacies concerning these familiar principles, as opposed to those that come from the employment relationship itself. Supporting this impression is the set of observations from the Mediation Service. Under the LR Act, mediators, although heavily influenced by court decisions, did actually operate outside the strict judicial approach. In this study they appeared to use all three principles equally in forming their decisions.

In addition, the results indicate that the pattern of decision-making remained essentially constant over the time period of the LR Act. This suggests that the standards of employer practice relating to natural justice have been firmly established, even that there is widespread acceptance of those standards, and that they are deemed legitimate and relevant to the employment relationship.

While this study describes the broad principles upon which the decision-makers base their decisions, it also offers a description of the specific issues involved in each of these principles. Under the opportunity to explain, the problem in the majority of cases was failure 
to provide the employee a chance to be heard. Within the inadequate investigation of the facts, the actual investigation was less of a problem than the interpretation of the facts and problems with the evidence. In those cases concerned with warnings given to the employee, the vast majority were deficient in the provision of sufficient warnings while only a quarter failed to provide adequate opportunity to improve. This last result is rather strange, for one would suspect that providing an opportunity to improve would imply a preceding warning. One possible reason may be the nature of the offence. Where allegations of misconduct and insubordination are involved it is reasonable to suggest that following a warning, behaviour is expected to improve immediately. In the matter of incompetence however, time must be given to employees so that they may improve their performance. Although unreported in the results, allegations of misconduct or insubordination were twice as frequent in this study as allegations of incompetence. Hence, for most of the cases, warning concerning inappropriate behaviour was more relevant than time given to improve work performance.

Within the substantive justification category, the major reason cited by the decisionmakers for lack of substantive justification was the inappropriateness of the discipline. This may have been due to the fact that the alleged offence was minor compared to the consequences of losing a job; or it may have been due to the lack of information available to the employer at the actual time of the dismissal. This matter of inappropriateness implies that there is some sort of standard or level of offence that warrants the loss of a job. However as this standard is determined very much by the different circumstances of the cases and the different opinions of the decision-makers, it is difficult to isolate quite what deserves dismissal and what doesn't.

$\mathrm{Cl} 17(3)$ basically stated that any failure to observe procedural fairness would not of itself render the dismissal unjustifiable if the dismissal was actually substantively justified (ECB 1990). Of the unjustified dismissal cases involved in the study, a little under half included specific lack of substantive justification while most involved some unfair procedure. Therefore removal of procedural fairness considerations from the unjustified dismissal decision would significantly impact on the decision process. The result would be that the number of cases found to be unjustified would drop from three-quarters to under one-half.

This conclusion assumes that the rationale for the decision will remain the same. In other words, the decision-makers will still define inadequacies of the employer's behaviour in terms of procedural inadequacies and, to comply with the requirements of the legislation, these matters will be specifically ignored. In view of the difficulties expressed of clearly differentiating between matters of substantive justification and procedural fairness, however, this seems unlikely. Instead, it seems likely that issues contained under the principles of the opportunity to explain, adequate investigation of the facts and adequate warnings, for example, would be incorporated into the proof of substantive justification. It may be suggested that it was unreasonable for the employer to dismiss the worker in a particular circumstance due to the fact that the employer had insufficient evidence (from the employee and the facts) to prove the appropriateness of the decision to dismiss. This anticipated flexibility is presuming the judiciary would respond in such a way.

Subtleties of definitions aside, the underlying inconsistency of $\mathrm{Cl} \mathrm{17(3)}$ is of interest. Since 1973, legislation has left to the courts the task of establishing the mechanisms by which the personal grievance procedure operates. As a result, the legal participants have applied their framework of rules to the labour relations area and have developed a body of case law which acknowledges and reflects the principles by which they operate. $\mathrm{Cl} 17(3)$ in effect sought to retain the judiciary as chief participant in the personal grievance structure, but at the same time prohibited their use of essential principles upon which they based their practice. 
This appears to be the most illogical aspect of the clause. Quite how the judiciary would have operated in this situation, however, is open to speculation.

\section{Conclusions}

By 1970 , industrial disruption due to dismissals was recognised to be a significant problem by the government of the day. The chosen solution was a legislated personal grievance structure whereby workers could appeal actions made against their interests. While offering a procedural structure, the legislation was vague as to the definitions and criteria to be used by the participants in the procedure. The role of establishing working definitions and criteria was left up to the judiciary. Due to the specific meaning given by the courts to the term unjustifiable, natural justice in the form of procedural fairness has become a recognised factor in the assessment of a dismissal appeal. Although subsequently discarded, $\mathrm{Cl}$ 17(3) of the ECB (1990) sought to remove the influence of procedural fairness on the decision process.

Effective unjustifiable dismissal legislation has been in place since 1973. However, little has been published by industrial relations scholars on the unjustifiable dismissal decision. The purpose of the research reported in this study has been to provide a description of this decision making process. The particular focus of the study has been the impact of procedural fairness so that the conclusions of the study could address the possible impact legislation such as $\mathrm{Cl} 17(3)$ of the ECB (1990) would have, had it been included in the Employment Contracts Act (1991).

Hypothetically, the impact of such legislation would be great. Most of the unjustified dismissal cases dealt with in the sample contained violations of fair procedure while under half were found to have substantive inadequacies. $\mathrm{Cl} 17(3)$ would have resulted in the exclusion of a significant criterion for assessing the adequacy of employer behaviour in the dismissal situation. Practically speaking, however, the paper expresses doubt that procedural fairness issues would have just vanished. It is suggested that the assessment of substantive justification would have become more rigorous and the former matters of procedural fairness would have become matters of substantive justification. Closing remarks focus on the lack of logic or thought underlying $\mathrm{Cl} 17(3)$. The paper suggests that, by assuming procedural issues can be cleanly separated from those of substance, $\mathrm{Cl} \mathrm{17(3)}$ would have retained the judiciary in the central administrative role in the personal grievance procedure, but at the same time removed the major principle through which the court would have performed this task.

\section{References}

- Anderson, G. (1983), Procedural fairness and unjustifiable dismissal, New Zealand Journal of Industrial Relations, 8(1): 1-10.

- Anderson, G. (1988), The origins and development of the personal grievance jurisdiction in New Zealand, The New Zealand Journal of Industrial Relations, 13(3): 257-275.

Banderet, M.E. (1986), Discipline at the workplace: a comparative study of law and practice, International Labour Review, 125(4): 383-399. 
(CCH) Commerce Clearing House (1991), The New Zealand Employment Law Guide, New Zealand.

Employment Contracts Bill (1990).

Geare, A. (1991), Employment Contracts Bill, Otago University: Department of Management Working Paper.

Hansard Parliamentary Debates (1990), Employment Contracts Bill -Introduction, Wednesday 19th December.

Hansard Parliamentary Debates (1991), Employment Contracts Bill -Second Reading, Tuesday 23rd April.

Hotop, S.D. (1985), Principles of Australian Administrative Law, 6th Edition, Australia, The Law Book Company Ltd.

Hughes, J. (1981), Emerging procedural requirements under section 117 of the industrial Relations Act 1973, Otago Law Review, 5(1): 162-171.

Hughes, J. (1989), Labour Law in New Zealand, Australia, The Law Book Company Limited.

Hughes, J. (1991), The role of labour law: the future of institutions and personal grievances, paper presented to the Employments Contract Seminar, Wellington, 15 February.

Hughes, J. (1992), Institutions and Grievance Handling, paper presented to The Employment Contracts Act: One Year On, Victoria University.

Industrial Relations Act (1973).

Mathieson, D.L. (1981), The lawyer, industrial conflict and the right to fire, The New Zealand Law Journal, 8: 216-227.

New Zealand Employers' Federation [INC] (1991), A review of the Employment Contracts Act.

New Zealand Law Commission, Report 18, (1991), Aspects of damages: Employment Contracts and the Rule in Addis $v$ Gramophone Co, Wellington, New Zealand.

Reeves, William Pember (1902), State experiments in Australia and New Zealand, Vol 2, Introduced by John Child (1969), MacMillan of Australia.

Selznik, P. (1969), Law, Society and Industrial Justice, United States of America, Russell Sage Foundation.

Summers, C.W. (1976), Individual Protection Against Unjust Dismissals: Time for a Statute, Virginia Law Review, 62(3): 481-532. 
Szakats, A. and M.A. Mulgan with contributions by M. Vranken (1990), Dismissal and Redundancy Procedures, 2nd edition, New Zealand, Butterworths.

\section{Cases}

(Hennessey) Auckland City Council v Hennessey, CA 29/3/82, ACJ 1982, pp699-702.

Auckland Local Authorities Officers' Industrial Union of Workers v Waitemata City Council', AC 1/5/80, ACJ 1980, pp35-36.

Taranaki Amalgamated Society of Shop Assistants and Related Trades IUW v CC Ward Ltd AC 1980, ACJ 1980, pp 123-124. 